УДК 165.21(045)

\title{
Михайло Цюрупа
}

\section{ДІАЛЕКТИКА МИРОТВОРЧИХ, ПРАВОВИХ ТА ВОЄННО-ПОЛІТИЧНИХ АСПЕКТІВ ПРОБЛЕМИ ДЕОКУПАЦІЇ ДОНБАСУ}

У статті проведено рефрлексивний аналіз ключових фракторів припинення збройного конфлікту на Сході України та повернення тимчасово окупованих окремих регіонів Донецької на Луганської областей під владу та юрисдикцію нашої суверенної держави.

Як відомо ще з найдавніших творів про війну та мир (Сунь Цзи), чим триваліше ведеться збройна боротьба, тим більше складнощів з ї̈ завершенням справедливим миром, тому для врегулювання збройного конфолікту на Донбасі зазвичай пропонується широкий спектр підходів: від компромісу з агресором до 
переможних планів i стратегій воєнного вирішення щодо звільнення захоплених територій. $У$ передвиборчий період українські політичні партії без теоретичного обгрунтування пропонують такі популістські підходи у річищі легкого вирішення складних воєнно-політичних проблем.

Наш підхід базується на виявленні полікаузальності причин і наслідків окупації АР Крим та ОРД і ЛО, на важливості дотримання принципів міжнародного права, гуманізму та прогресу при проведенні державної політики, на визнанні серед сукупності фракторів ключового - діяльнісного фрактору миротворчості багатонаціональних сил, френомен якого не експлікований, теоретично не прояснений стосовно особливостей соціально-політичної та гуманітарної ситуації на Донбасі.

Миротворчість як порівняно новий міжнародно-правовий та гуманітарний феномен віднесений до напіввоєнних заходів світового співтовариства, яке, згідно Статуту ООН, вживає «інших заходів» для відновлення миру, запобігання гуманітарним катастрофрам. Його суперечлива природа випливає із того, що з одного боку ООН не тлумачить свій Cтатут, як «право на втручання у ті справи, які по суті входять у компетенцію будь-якої держави, а з іншого боку - має вжити всі заходи для встановлення та збереження мupy.

Особливістю застосування багатонаціональних миротворчих сил на Сході України є ї діяльність на основі Cтатуту ООН, синтез гуманітарних, політичних, соціальних місій, військово-цивільного контролю над гуманітарною ситуацією, яка може привести до катастрофии.

Ключові слова: гуманітарна криза, миротворчі операції, де окупація Донбасу, Україна, російська агресія.

\section{Michael Tsyurupa}

\section{DIALECTICS OF PEOPLE, LEGAL AND MENTAL POLITICAL ASPECTS OF THE PROBLEM OF DONBASU BUILDING}

The article provides reflexive analysis of the key factors of the cessation of armed conflict in the East of Ukraine and the return of the temporarily occupied regions of Donetsk to Lugansk oblasts under the authority and jurisdiction of our sovereign state.

As the oldest works on war and peace (Sun Tzu) are known, the longer the armed struggle is, the more difficult it ends with a just world, therefore, a wide range of approaches are usually proposed for resolving the armed conflict in the Donbass: from a compromise with the aggressor to victorious plans and strategies for a military solution to the liberation of captured territories. In the pre-election period, Ukrainian political parties, without theoretical justification, propose such populist approaches to solving difficult military-political problems.

Our approach is based on the identification of the causes and consequences of the occupation of the Autonomous Republic of Crimea and the ORD and LO, the importance of adhering to the principles of international law, humanism and progress in the conduct of state policy, recognition of the factors of the key - activity factor of the peacemaking of multinational forces whose phenomenon is not explicated, theoretically unclear as to the peculiarities of the socio-political and humanitarian situation in the Donbass.

Peacekeeping as a relatively new international legal and humanitarian phenomenon is attributed to the peaceful measures of the world community, which, according to the UN Charter, is taking "other measures" for the restoration of peace and the prevention of humanitarian catastrophes. His controversial nature follows from the fact that, on the one hand, the United Nations does not interpret its Statute, as "the right to intervene in cases that are essentially within the competence of any state, and on the other hand, it must take all measures for the establishment and preservation of peace.

he peculiarity of the use of multinational peacekeeping forces in the East of Ukraine is its work on the basis of the UN Charter, the synthesis of humanitarian, political, social missions, military and civilian control over the humanitarian situation, which could lead to disaster.

Key words: humanitarian crisis, Peacekeeping operations, the de occupation of the Donbas, Ukraine, Russian aggression.

Постановка проблеми. Серед найактуальніших і водночас найскладніших питань суспільного, а для більшості свідомих громадян й індивідуального буття у сьогочасній Україні, є завдання збереження, захисту та відновлення територіальної цілісності української держави, яка від лютого 2014 року зазнає агресивного нападу Російської Федерації, що визнано на рівні міжнародних інститутів та органів легітимної влади нашої країни. У Законі України 2018 року «Про особливості державної політики...» вказано, що

«державна політика із забезпечення державного суверенітету України на тимчасово окупованих територіях у Донецькій та Луганській областях базується на Конституції та законах України, міжнародних договорах, згода на обов'язковість яких надана Верховною Радою України, принципах і нормах міжнародного права» [1, с. 3].

Україна і раніше зазнавала утисків з боку сусідів. Про це з болем повідомлялось в «Історії русів». Анонімний автор "Історії Русів" писав, що "ця 
країна начеб створена або приречена на руїну од частих навал чужинців, а ще частіших наскоків та січей от народів сусідніх i, зрештою, од ненастанних міжусобиць і побоїщ..." [ 2, с. 33].

Історична практика повернення суверенітетуна всю територію мало у чому може нам допомогти, адже окуповані території, як правило, звільняються в результаті завершення «класичної» війни. Це певний підсумок збройної боротьби, що, між іншим, може призводити до появи «нео» окупованих територій. СРСР фактично захопив-окупував м. Кенігсберг, де знаходиться могила всесвітньо відомого мислителя I. Канта, який мріяв «Про вічний мир». У цій роботі він побудував погляд на майбутнє європейських народів з моральної точки зору, тоді як агресори ніколи не зважають на морально-правові засади міждержавного життя. Ця так звана «ідеалістична» концепція міжнародних відносин, згідно думок американського політолога А. Хейвуда, має неабиякий методологічний сенс.

Розглядаючи взаємовідносини між державами, І. Кант заявляв: "Жодна держава не повинна шляхом насильства втручатись у політичне будівництво і управління інших держав" [3, с. 262], бо втручання сторонніх держав означає порушення прав незалежного народу. Він був рішучим противником усіляких брудних інсинуацій з боку тих держав, які 3 метою послаблення свого противника вдаються до заслання «вбивць з-за рогу (percussores), отруйників (venefici), порушення вимог капітуляції, підбурювання і зради (perduellio) в державі противника». Ці ідеї великого мислителя справедливо підкреслюють українські дослідники В. Остапенко та В. Ряшко [7, c.263].

У наші дні відзначення 100 річниці завершення Першої світової війни доречно нагадати, як на моменті несправедливого завершення міждержавних воєн наголосив перший 3 діючих президентів США, який побував у післявоєнній Європі, Вудро Вільсон. Він засудив дії держав-переможців Німеччини у світовій війні, бо ті намагались не будувати плани мирного співжиття, а якомога більше отримати поживи, зокрема, від приєднання «нових» територій $[11$, c. 27 ].

Коли звільнення окупованих територій відбувається через збройну боротьбу (війну), то це чиниться начебто автоматично, бо повернення рідної, у міжнародно визнаних кордонах території, $є$ однією із цілей збройної боротьби. Це реалізація суверенного права будь-якої постраждалої країни, у тому числі й України, на відновлення і збереження територіальної цілісності (правовий аспект) і засад морального права.

У Законі України 2018 року «Про особливості державної політики...» мовиться про використання на чітко визнаних правових началах силових важелів держави за підтримки світової спільноти, близьких союзників, змушення окупантів до припинення окупації.
Неначе передбачаючи такий стан речей, Ліон Фейхвангер писав: «Кого війна не навчила, що правда без сили не є правда, тому вже нічого не допоможе» [11]. Отже, йдеться про пошук нестандартного рішення екзистенційно важливого завдання українського соціуму. Проте, спочатку звернемось до історії «деокупації» країн Європи.

Виклад основного матеріалу. Філософи нескореної Франції у часи окупації частини країни німецькими військами та проявів колабораціонізму зі злочинним режимом запропонували «філософрію героїзму», - писала французька дослідниця Е. Рудинеско [9]. Частина 3 них взяла активну або посильну участь у збройній боротьбі. Інша частина, як колись радив і діяв Й. Фіхте при наполеонівському нашесті, обрала інтелектуальну зброю нищівної критики окупаційного режиму. Зрештою, була й частка тих мислителів, які покладалась на внесок перших і других у боротьбі-спротиві окупації.

Сьогодні, вже за інших соціально-політичних, історичних, морально-релігійних обставин, слід визнати, що організований опір окупаційній владі та незаконним збройним формуванням на Донбасі практично відсутній. Це перший вихідний пункт, щодо якого слід модифікувати принцип міжнародного права дотримання правових основ деокупації 3 опертям на принципи гуманізму та людяності, нейтралітету та безсторонності. Громадян, які залишились на окупованих територіях ОРД і ЛО, не слід вважати колабораціоністами, це громадяни нашої держави, що лишились на території, не підконтрольній законній владі, адже не приєднались до біженців люди переважно похилого віку. Вони ведуть себе пасивно з різних причин, здебільшого через страхи, від розпачу, через безвихідь. У цілому питання цивільного населення, що знаходиться на окупованих територіях, врегульовано міжнародним гуманітарним правом. Воно має підкорятись встановленому правовому режиму.

У Законі України 2018 року «Про особливості державної політики...» констатується, що тимчасова окупація $€$ незаконною, тоді як державна політика 3 метою деокупації базується на Конституції України, міжнародних договорах, принципах і нормах міжнародного права. Однак ці фундаментальні положення не ставлять питання механізму впровадження цього законного права у життя.

Отже, маємо враховувати те, що склалась нестандартна, «не класична» ситуація розробки плану дій (дорожньої карти) для країни у стані «гібридної війни», яка не має традицій правового, воєнно-політичного та морального регулювання. У цьому стані Україна зазнала втрати частини суверенітету та не може поширити владу на всю свою законну територію. На виконання завдання деокупації з політично-практичного боку зусилля повинні бути спрямовані не тільки центральними та місцевими органами влади, силовими інституціями, системою правосуддя, а й громадськими організаціями, у тому числі і гуманітарного профілю. 
На це повинна працювати і інформаційнопропагандистська сфрера суспільства.

Смисл діалектичної методології ми вбачаємо у рефлексивному аналізові зв'язків різноманітних факторів, які визначають соціально-політичну та гуманітарну ситуацію, зі знаходженням домінант впливу на негативні соціально-політичні, економічні, екологічні процеси.

У вище наведених міркуваннях щодо важливості фрілософських ідей Імануїла Канта, які лягли в основу діяльності об'єднаної Європи, не були присутні положення щодо практичних дій реалізації плану, щодо практичних кроків у напрямку досягнення цієї величної мети. Там не було того, що колишній президент США Буш-молодший у першому посланні до Конгресу та в подальшому у виступі в академії у Вест-Пойнті озвучив у вигляді афоризму: «Шлях до миру - це шлях дії».

Наголос на реалізації дієвого фрактору миротворчості, актуалізованого конкретною ситуацією модифрікації «класичних» війн у «гібридну», перетворення не підконтрольних владі територій в окуповану зону з позірним суверенітетом, $є$ головний лейтмотив нашої статті.

Стосовно дії силових структур, у першу чергу Об'єднаних Сил, на які покладено реалістичне завдання стримувати ворога та у разі необхідності виконати функцію індивідуальної або колективної самооборони держави згідно Статуту ООН (ст. 47, 51), то маємо націлити їх на активний захист лінії розмежування та недопущення просування ворога на вже звільнені території.

Напіввоєнними і гуманітарними акціями $є$ плани застосування миротворчих місій на Донбасі. Для цих заходів, за підрахунками української сторони, потрібно приблизно 40 тис. миротворців із багатонаціонального контингенту $\mathrm{OOH}$, головною вимогою до яких є нейтралітет і неупередженість.

Проблема миротворчості піднімалась в Україні в дослідженнях О. Кузьмука, В. Неліпа, О. Мережко, М. Цюрупи [5; 6; 12$]$.

Філософсько-соціологічний смисл миротворчості полягає у тому, що на основі принципів нейтралітету, безсторонності, під егідою авторитетного міжнародного органу світова спільнота використовує так зване «надзвичайне право» 3 метою недопущення розростання збройного конфлікту до небезпечної ситуації громадянської чи локальної війни, а також погіршення гуманітарної кризи до гуманітарної катастрофи, яка вже сталась, наприклад, у Ємені.

Миротворчість має бути віднесена до активної складової міжнародної безпекової політики, яка має свій початок з відносно недавнього часу. Незважаючи на дуже просту назву та часте цитування Біблійського зауваження „Блаженні миротворці”, цей міжнародно-політичний термін віддзеркалює складний феномен проведення міжнародних силових акцій із застосуванням наднаціональних збройних сил у конфліктогенних регіонах планети, де відбуваються збройні конфлікти між різними соціальними групами, етносами, народами чи навіть країнами, які загрожують всезагальному миру.

Складність фрактору миротворчості починається навіть із визначення. Як вказував Шаші Тхарур, спеціальний помічник Заступника Генерального секретаря ООН 3 миротворчих операцій, у Об'єднаних націях не давали визначення цих реалій спеціально на рівні «права $\mathrm{OOH}$, щоб не політизувати цей вид діяльності.

У вітчизняній науковій традиції прийнято вважати миротворчістю «міжнародні дії або заходи, які здійснюються за рішенням РБ ООН, ОБСЕ, інших регіональних організацій, які несуть відповідальність у сфрері підтримки міжнародної безпеки, а також дії багатонаціональних сил, що знаходяться під їх контролем».

Проблемними питаннями миротворчості залишаються їхня недостатня ефективність по припиненню збройної боротьби, можливість втрат «блакитних шоломів» (у 2018 р. році загинуло біля 60 миротворців, а у 1995 р. у колишній Югославії загинуло 200 осіб та 1500 було поранено), розмежування політичних та гуманітарних зусиль, міжнародно-правова база миротворчості.

Президент МКЧЧ у завершальному десятилітті 20 століття Корнеліо Соммаруга вважав, що слід не тільки розмежовувати, але й синтезувати різні зусилля спільноти по відновленню миру як перший крок по політичному врегулюванню. Політичну волю нічим не можна замінити, це не тільки умова ефеективності операцій по встановленню та підтриманню миру, гуманітарної діяльності, але й головна мета у конфліктогенному регіоні. Досвід Руанди 1994 року, показав, що більше 25 років триває відновлення довіри між етнічними групами багатостраждальної країни, як це раніше було у Сомалі, Ліберії, колишній Югославії [4, c. 213 ]. Поки що у ОРД і ЛО спостерігаються лише окремі дії міжнародних (недержавних) гуманітарних організацій. Політичні зусилля сторін, дотичних до конфлікту, «застрягли» з 2015 р. Але діяти потрібно негайно, адже, як писав 2500 років потому Сунь Цзи, «затяжна тривала війна не приносить нікому користі» $[10$, c. 18].

Очевидно, проблема введення миротворців на Донбасі має розглядатися як воєнно-політична та гуманітарна водночас. Пропонуємо напрямки найважливіших видів діяльності, адекватних і актуальних, на нашу думку, для ситуації на Сході України:

1. захист мирних місій, які надають гуманітарну допомогу постраждалим, у першу чергу, цивільним особам похилого віку, дітям, хворим;

2. забезпечення проведення в життя несилових міжнародних санкцій проти порушників миру в зоні конфлікту шляхом розслідування військових злочинів, включно із затриманням підозрюваних і передачею справ у Гаазький Трибунал (камору); 
3. реалізація мирного плану легітимних структур, або міжнародних інституцій, у першу чергу, Мінських домовленостей та нових рішень Паризького саміту 2018 р.

Важливий момент миротворчості полягає у тому, що захист цивільних осіб, гуманітарні принципи та гуманітарна діяльність мають бути скоординовані із зовнішньою, внутрішньою (соціальна і гуманітарна політика) та воєнною політикою. Президент України П. Порошенко з нагоди 100 річчя завершення Першої світової війни наголосив, що сьогодні введення миротворців на Донбасі - найбільш дієвий спосіб врегулювати складну, суперечливу соціальнополітичну та гуманітарну ситуацію в регіоні [8]. Активна інформаційна політика та міжнародна дипломатія сприятимуть миротворчості та посиленню гуманітарних аспектів деокупації Донбасу.

Висновки. Таким чином, реальним шляхом до звільнення окупованих територій ОРД і ЛО $є$ діяльність по сприянню соціально-економічному розвитку окупованих районів, інтеграції їх у одне ціле із, так би мовити, «материнською» територією на визнаній міжнародним товариством правовій базі, із наполяганням на гуманітарній складовій.

1. Закон України «Про особливості державної політики із забезпечення державного суверенітету України на тимчасово окупованих територіях у Донецькій та Луганській областях» // Відомості Верховної Ради (ВВР). - 2018. - № 10. - С. 54.

2. Історія Русів / Пер. І. Драча. - К.: Веселка, 2003. - 366 c.

3. Кант И. К вечному миру / Иммануил Кант. Сочинение: в 6-ти т. / Под общ. ред. В.Ф. Асмуса и др. - М.: Мысль, 1966. - Т. 6. -743 с.

4. Корнелио Саммаруги. Гуманитарная деятельность и операции по поддержанию мира / К. Саммаруги // Журнал Международного Комитета Красного Креста. - 1997. - Август-сентябрь. - С. 213 $-219$.

5. Кузьмук О.І. Миротворча діяльність у спектрі пріоритетних функцій Збройних Сил України XXI століття / О.І. Кузьмук // Наука і оборона. - 2001. - № 4. - C. $5-12$.

6. Неліп М.І., Мережко О.О. Силовий захист прав людини. Питання легітимності в сучасному міжнародному праві / М.І. Неліп, О.О. Мережко. - К.: Наукова думка, 1998. - 278 с.

7. Остапенко В.І., Ряшко О.І. Кант: Війна і мир. Важкий шлях до вічного миру / В.І. Остапенко, О.І. Ряшко. - [Електронний ресурс] // Режим доступу: https://www.google.com/url?sa=t\&rct=j\&q=\&esrc=s\&sour $c e=$ web\&cd=2\&ved=2ahUKEwi8vKqc8MHeAhXillsKHXi XCWcQFjABegQIABAC\&url=http\%3A\%2F\%2Fena.Ip.ed u.ua\%2Fbitstream\%2Fntb\%2F30078\%2F1\%2F032_209 214.pdf\&usg=AOvVaw1PSsXgi7omitKi55bRtqRY

8. Порошенко П. Миротворці ООН - краще вирішення для врегулювання на Донбасі / Петро Порошенко. - [Електронний ресурс] // Режим доступу: https://www.ukrinform.ua/rubric-polytics/2545587- porosenko-mirotvorci-oon-krase-risenna-dlavreguluvanna-na-donbasi.html.

9. Рудинеско Е. Філософи в обіймах бурі / Е. Рудинеско. Пер. з франц. - К.: Ніка-Центр, 2007. 206 c.

10. Сунь Бін. Трактат про військове мистецтво / С. Бін. Пер. $з$ кит. П. Шеремета, Львів: Видавництво Старого лева, 2015. - 102 с.

11. Творцы Всемирной истории. От Первой мировой войны до современности. Пер. с франц. Издания Larusse. - М.: Арт-Родник, 2004. - 326 с.

12. Фейхвангер Лион. Изгнание / Лион Фейтвангер. Пер. с нем. - М.: Иностранная литература, 1960. - 528 с.

13. Цюрупа М.В. Миротворчі операції як міжнародно-правовий та воєнно-гуманітарний феномен / М.В. Цюрупа. - К.: КВГІ, 2003. - 78 с.

\section{References}

1. 2018. Zakon Ukrainy «Pro osoblyvosti derzhavnoi polityky iz zabezpechennia derzhavnoho suverenitetu Ukrainy na tymchasovo okupovanykh terytoriiakh $u$ Donetskii ta Luhanskii oblastiakh» [Law of Ukraine "On the peculiarities of state policy on ensuring state sovereignty of Ukraine in temporarily occupied territories in the Donetsk and Luhansk oblasts"]. Vidomosti Verkhovnoi Rady (VVR). № 10. S. 54 [in Ukrainian].

2. 2003. Istoriia Rusiv [History of Rus]. Per. I. Dracha. K. Veselka. 366 s. [in Ukrainian].

3. Kant Y., 1966. K vechnomu myru [To eternal peace]. Sochynenye $v$ 6-ty t. Pod obshch. red. V.F. Asmusa y dr. M. Mыsl. T. 6. 743 s. [in Russian].

4. Kornelyo Sammaruhy. 1997. Humanytarnaia deiatelnost y operatsyy po podderzhanyiu myra [Humanitarian activities and peacekeeping operations]. Zhurnal Mezhdunarodnoho Komyteta Krasnoho Kresta. S. $213-218$ [in Russian].

5. Kuzmuk O.I., 2001. Myrotvorcha diialnist u spektri priorytetnykh funktsii Zbroinykh Syl Ukrainy XXI stolittia [Peacekeeping activities in the spectrum of priority functions of the Armed Forces of Ukraine in the XXI century]. Nauka i oborona. № 4. S. 5-12 [in Ukrainian].

6. Nelip M.I., Merezhko O.O., 1998. Sylovyi zakhyst prav liudyny. Pytannia lehitymnosti $v$ suchasnomu mizhnarodnomu pravi [Power protection of human rights. The question of legitimacy in modern international law]. K. Naukova dumka. 278 s. [in Ukrainian].

7. Ostapenko V.I., Riashko O.I. Kant: Viina i myr. Vazhkyi shliakh do vichnoho myru [Kant: War and Peace. A difficult path to eternal peace]. URL: https://www.google.com/url?sa=t\&rct=j\&q=\&esrc=s\&sour $\mathrm{ce}=$ web\&cd=2\&ved=2ahUKEwi8vKqc8MHeAhXillsKHXi XCWcQFjABegQIABAC\&url=http \%3A\%2F\%2Fena.Ip.ed u.ua\%2Fbitstream\%2Fntb\%2F30078\%2F1\%2F032_209 214.pdf\&usg=AOvVaw1PSsXgi7omitKi55bRtqRY [in Ükrainian].

8. Poroshenko P. Myrotvortsi OON - krashche vyrishennia dlia vrehuliuvannia na Donbasi [UN peacekeepers are the best solution for settling in the Donbass. URL: https://www.ukrinform.ua/rubric- 
polytics/2545587-porosenko-mirotvorci-oon-krase-

risenna-dla-vreguluvanna-na-donbasi.html [in Ukrainian].

9. Rudynesko E., 2007. Filosofy $v$ obiimakh buri [Philosophers in the arms of the storm]. Per. $z$ frants. K. Nika-Tsentr. 206 s. [in Ukrainian].

10. Sun Bin, 2015. Traktat pro viiskove mystetstvo [Treatise on martial arts]. Per. z kyt. P. Sheremeta. Lviv. Vydavnytstvo Staroho leva. $102 \mathrm{~s}$. [in Ukrainian].

11. 2004. Tvortsy Vsemyrnoi ystoryy. Ot Pervoi myrovoi voiny do sovremennosty [World History
Creators. From World War I to the present]. Per. s frants. Yzdanyia Larusse. M. Art-Rodnyk. 326 s. [in Russian].

12. Feikhvanher Lyon, 1960. Yzghnanye [Exile]. Per. s nem. M. Ynostrannaia lyteratura. $528 \mathrm{~s}$. [in Russian].

13. Tsiurupa M.V. 2003. Myrotvorchi operatsii yak mizhnarodno-pravovyi ta voienno-humanitarnyi fenomen [Peacekeeping operations as an international legal and military-humanitarian phenomenon]. K. KVHI. 78 s. [in Ukrainian]. 